九州大学学術情報リポジトリ

Kyushu University Institutional Repository

\title{
Inhibitory components from the buds of clove (Syzygium aromaticum) on melanin formation in B16 me lanoma cells
}

\section{Arung, Enos Tangke}

Department of Agro-environmental Sciences, Faculty of Agriculture, Kyushu University

Department of Forest Product Technology, Faculty of Forestry, Mulawarman University

Matsubara, Eri

Department of Agro-environmental Sciences, Faculty of Agriculture, Kyushu University

Kusuma, Irawan Wi jaya

Department of Forest Product Technology, Faculty of Forestry, Mulawarman University

Sukaton, Edi

Department of Forest Product Technology, Faculty of Forestry, Mulawarman University

他

http://hdl. handle. net/2324/25502

出版情報：Fitoterapia. 82 (2)，pp. 198-202，2011-03. Elsevier

バージョン：

権利関係: (C) 2010 Elsevier B.V. 
1 Inhibitory components from the methanol extract of the buds of clove (Syzygium

2

3

4

7 1.Department of Forest and Forest Products Sciences, Faculty of Agriculture, Kyushu

8 University, Fukuoka, 812-8581, Japan

9 2.Department of Forest Product Technology, Faculty of Forestry, Mulawarman

10 University, Samarinda, 75123, Indonesia

\section{aromaticum) on melanin formation in B16 melanoma cells}

Kuniyoshi Shimizu ${ }^{1}$, Ryuichiro Kondo ${ }^{1}$

12

13

14

15

16

17

18

19

20

21

22

23

24

25

26

27

28

29

30

31

(1)

.

5

8

9

(1)

2

30




\section{Abstract}

In the course to find a new whitening agent, we evaluated an inhibitory effects of methanol extract from bud of clove (Syzygium aromaticum) on melanin formation in B16 melanoma cells. The active compounds, eugenol and eugenol acetate showed melanin inhibition of $60 \%$ and $40 \%$ in B16 melanoma cell with less cytotoxicity at the concentration of 100 and $200 \mu \mathrm{g} / \mathrm{mL}$, respectively.

Keywords : eugenol, eugenol acetate, Syzygium aromaticum, B16 melanoma cells, melanin inhibition

\section{Introduction}

Melanocytes are specialized cells in the skin that find their embryonic origin at the neural crest. During embryonic development, melanoblasts migrate to reach the basal layer of the epidermis where they differentiate to mature melanocytes possessing the complete machinery to ensure melanin synthesis and distribution within the skin. Melanin synthesis takes place within specialized intracellular organelles named melanosomes [1].

Melanin may be overproduced due to chronic sun exposure, melasma, or other hyperpigmentation diseases. Therefore, a number of depigmenting agents have been developed for cases of undesirable skin discoloration [2]. Up to now, most research on the regulation of melanogenesis has focused on the factors affecting tyrosinase, which catalyzes the rate-limiting step of the melanin biosynthesis pathway, specifically, the conversion of $\mathrm{L}_{\mathrm{L}}$ tyrosine to $\mathrm{L}-3,4$-dihydroxyphenylalanine (L-DOPA) and subsequently to DOPA quinone. Kojic acid [3] and arbutin [4] are known as tyrosinase inhibitors and are 
used as skin-whitening cosmetics.

In Indonesia, where herbal medicine has been popular, more than 1300 species are known as medicinal plants, called Jamu [5]. The uses of Jamu fall into four categories of medicine: health care, beauty care (cosmetics), tonics, and bodily protection [6]. The use of traditional medicines has increased in recent years, and provides an interesting, largely unexplored source for the development of potential new drugs.

The clove tree (Syzygium aromaticum) named as "Cengkeh" in Indonesian was first cultivated on some islands of the Moluccas, Indonesia. In Southeast Asia, however, the clove is not much used for flavour food; medicinal use of both the clove (the flower bud) and the mother-of-clove (the fruit) has predominated. Cloves suppress toothache and halitosis; they are also a stimulant and carminative. Now, more than $90 \%$ of the cloves are used along with tobacco to produce 'kretek' cigarettes, which are smoked mainly in Indonesia [7]. The S. aromaticum is an evergreen tree and cloves, clove oil and oleoresin are commercial products. It is native to Molucca Island of Indonesia. The major clove-producing countries are Indonesia, Tanzania, Sri Lanka, Madagascar and, on a limited scale, India. In India it is grown in Kerala, Tamilnadu, Karnataka, Andaman and Nicobar Island over an area of 1735 hectares. The stem, unopened buds and leaves are normally used for extraction of essential oil. Owing to various kind of biological activities, clove oil finds extensive use in dental formulations, tooth paste, breath freshner, mouth washes, soaps, cosmetic items and insect repellent [8].

In present study, we evaluated the melanin biosynthesis inhibitory effect of the methanol extract from the buds of $S$. aromaticum on B16 melanoma cells in order to identify potential depigmenting agents such as skin-whitening cosmetics. 


\section{Experimental}

81

82

\section{Reagents}

Eugenol, $\mathrm{NaOH}$ and DMSO were purchased from Wako Pure Chemical Industries, Ltd (Osaka, Japan). Eugenol and eugenol acetate were from TCI (Tokyo Chemical Industry, Tokyo, Japan). The 3-(4,5-dimethyl-thiazol-2-yl)-2,5-diphenyl tetrazolium bromide (MTT) from Sigma (St. Louis, MO), EMEM from Nissui Chemical Co (Osaka, Japan). Essential oil of clove was purchased from GAIA Essential Oil. The Ethylenediaminetetraacetic acid (EDTA) from Dojindo Co, (Kumamoto, Japan). Other chemicals are of the highest grade commercially available.

\section{Plant material}

The bud of clove ( $S$. aromaticum) was collected from traditional market in Samarinda, East Kalimantan, Indonesia on July, 2009. The voucher specimen was deposited in Wood Chemistry Laboratory, Department of Forest Product Technology, Faculty of Forestry, Mulawarman University.

\section{Preparation of plant extract}

The dried bud of clove (14.9 g) was extracted with methanol at room temperature for $24 \mathrm{~h}$. The extract solution was filtered and concentrated in vacuo, to obtain the crude methanol extract $(5.9 \mathrm{~g})$.

\section{Isolation of eugenol and eugenol acetate}

Methanol extract of $S$. aromaticum $(1.02 \mathrm{~g})$ that showed potent inhibitory effect of melanin production in B16 melanoma cells, was separated by silica gel column (800 g 
of Wakogel C-200, $3.5 \times 60 \mathrm{~cm})$ and eluted with $n$-hexane/EtOAc [10:0 (150 mL), 9:1 (100 mL), 8:2 (100 mL), 7:3 (200 mL), 6:4 (200 mL), 5:5 (100 mL), 4:6 (400 mL), 3:7 (200 mL), 2:8 (100 mL), 1:9 (100mL)] and EtOAc/MeOH [9:1 (100 mL), 7:3 (100 mL), 5:5 (200 mL), 3:7 (200 mL), 1:9 (100 mL), 0:10 (850 mL)] to give fifty six fractions (Fr 1 to Fr 56). Fraction 4 (184.3 mg) was oily, the highest content and gave pleasant aroma. By using GC-MS, this fraction was analyzed and compared with the standard compounds such as eugenol and eugenol acetate.

\section{GC-MS analysis}

Fraction 4 and Essential oil of clove was dissolved in acetone and subjected to qualitative analysis by using GC-MS instrument (GC-17A, QP-5050). The instrument equipped with a column : DB-5 (30 $\mathrm{m} \times 0.25 \mathrm{~mm}$ i.d., $0.25 \mu \mathrm{m}$ film thickness, $\mathrm{J} \& \mathrm{~W}$ Scientific Inc.), split ratio : 1:50, and running with temperature program : INJ $250^{\circ} \mathrm{C}$ DET $250{ }^{\circ} \mathrm{C}, 50{ }^{\circ} \mathrm{C}$ at $3{ }^{\circ} \mathrm{C} / \mathrm{min}$. hold to $250{ }^{\circ} \mathrm{C}$ at $7{ }^{\circ} \mathrm{C} / \mathrm{min}$ and $250{ }^{\circ} \mathrm{C}$ at $10{ }^{\circ} \mathrm{C} / \mathrm{min}$. hold.

\section{Cell culture} were maintained in EMEM supplemented with $10 \%(\mathrm{v} / \mathrm{v})$ fetal bovine serum (FBS) and $0.09 \mathrm{mg} / \mathrm{mL}$ theophylline. The cells were incubated at $37^{\circ} \mathrm{C}$ in a humidified atmosphere of $5 \% \mathrm{CO}_{2}$. 

melanoma cells

This assay was determined as described by Arung et al [9]. Briefly, confluent cultures of B16 melanoma cells were rinsed in phosphate-buffered saline (PBS) and removed from the plastic using $0.25 \%$ trypsin/EDTA. The cells were placed in two plates of 24-well plastic culture plates (1 plate is for determining of melanin and other is

134 for cell viability) at a density of $1 \times 10^{5}$ cells/well and incubated for $24 \mathrm{~h}$ in media prior

135 to being treated with the samples. After $24 \mathrm{~h}$, the media were replaced with $998 \mu \mathrm{L}$ of fresh media and $2 \mu \mathrm{L}$ of DMSO was added with or without (control) the test sample at various concentrations $(n=3)$ and arbutin was used as a positive control. The cells were incubated for an additional $48 \mathrm{~h}$, and then the medium was replaced with fresh medium containing each sample. After $24 \mathrm{~h}$, the remaining adherent cells were assayed (see below). removing the medium and washing the cells with PBS, the cell pellet was dissolved in $1.0 \mathrm{~mL}$ of $1 \mathrm{~N} \mathrm{NaOH}$. The crude cell extracts were assayed using a micro plate reader (Bio-Tek, USA) at $405 \mathrm{~nm}$ to determine the melanin content. The results from the cells treated with the test samples were analyzed as a percentage of the results from the control culture.

Cell viability was determined by use of the micro culture tetrazolium technique 
152 (MTT). The MTT assay provides a quantitative measure of the number of viable cells

153 by determining the amount of formazan crystals produced by metabolic activity in 154 treated versus control cells. Culture was initiated in 24 -well plates at $1 \times 10^{5}$ cells per 155 well. After incubation, $50 \mu \mathrm{L}$ of MTT reagent [3-(4, 5-dimethyl-2-thiazolyl)-2, 156 5-diphenyl-2H-tetrazolium bromide in PBS $(5 \mathrm{mg} / \mathrm{mL})]$ was added to each well. The 157 plates were incubated in a humidified atmosphere of $5 \%$ of $\mathrm{CO}_{2}$ at $37^{\circ} \mathrm{C}$ for $4 \mathrm{~h}$. After 158 the medium was removed, $1.0 \mathrm{~mL}$ isopropyl alcohol (containing $0.04 \mathrm{~N} \mathrm{HCl}$ ) was added 159 into the plate, and the absorbance was measured at $570 \mathrm{~nm}$ relative to $630 \mathrm{~nm}$.

\section{Results and discussion}

Clove oil ( $S$. aromaticum) is widely used as a perfume and food flavoring, as a medicine for the treatment of asthma and various allergic disorders in Korea and as a general antiseptic in medical dental practices. The clove oil might also be used as an chemopreventative agent [10]. Srivastava, et al. [8] reported that clove oil has some properties such as anthelmintic, analgesic, antibacterial, antifungal and anticarcinogenic.

In present study, we evaluate anti melanogenesis property of the methanol extracts of the buds of clove. The methanol extracts were assayed by using B16 melanoma cells in order to evaluate the inhibition of melanin formation and cell viability. In Figure 1, the inhibition of methanol extracts of clove on melanin formation in B16 melanoma cells was shown at various concentrations. At the concentration of $50 \mu \mathrm{g} / \mathrm{mL}$, the methanol extract of clove showed potent melanin formation inhibitory activity more than $40 \%$ with less cytotoxicity. The similar result was depicted by arbutin, as positive control.

Based on this result, we separated the methanol extract by using silica gel column 
fractionation in order to find the active compounds. This separation, gave 56 fractions and fraction 4 (C-4) was oily, high content and pleasant smell. Therefore, we focused on fraction C-4 to evaluate its anti melanogenesis effect. In Figure 2, C-4 showed melanin inhibition on B16 melanoma cells about $25 \%$ with less cytotoxicity at $100 \mu \mathrm{g} / \mathrm{mL}$ of concentration. By GC-MS analysis (Figure 3), we have compared the standard compound, such as eugenol and eugenol acetate with fraction C-4. The GC-MS data of standards obviously indicated that fraction C-4 contained eugenol and eugenol acetate (Figure 4). Eugenol was the main compound in this fraction (Figure 3). It had been reported that the essential oil obtained by hydro distillation of buds of clove, contained eugenol and $\beta$-caryophyllene as dominant compounds $[8,11,12]$; eugenol and eugenol acetate as abundant compounds [13]. In methanol extract of bud of clove, Son et al, [14] reported that eugenol was isolated with some phenolic compounds.

Next, we evaluated the effect of eugenol and eugenol acetate which were dominantly contained in oily fractions on melanin formation in B16 melanoma cells as more than $42 \%$ with less cytotoxicity $(5 \%)$ at $100 \mu \mathrm{g} / \mathrm{mL}$ but high concentration, at 200 $\mu \mathrm{g} / \mathrm{mL}$, it showed cytotoxicity of $23 \%$. Eugenol acetate attenuated melanin formation about $40 \%$ with less cytotoxicity (14\%) at $200 \mu \mathrm{g} / \mathrm{mL}$ and depicted cytotoxicity effect of $71 \%$ at $250 \mu \mathrm{g} / \mathrm{mL}$. In addition, we tested the melanin formation of essential oil of clove in order to compare the effect on it. In Figure 7, it depicted the effect of essential oil of clove which showed cytotoxicty on B16 melanoma cell rather melanin formation inhibition. The presence of $\beta$-caryophyllene and isoeugenol in essential oil of clove may cause the cytotoxicity effect as shown in Figure 8. In our knowledge, this is the first 
report that methanol extract from bud of clove, eugenol and eugenol acetate exihibited melanin inhibition in B16 melanoma cells.

In conclusion, eugenol and eugenol acetate are promising compounds that could be useful for treating hyperpigmentation, as a skin-whitening agent with pleasant smell. However, it should be noted that safety is a primary consideration for its practical use in humans.

206

\section{Acknowledgement}

This research supported by Japan Society for the Promotion of Science (JSPS) for Postdoctoral Fellow of Foreign Researchers.

\section{References}

1. Busca R, Ballotti R. Pigment Cell Res 2000; 13: 60

2. Wang KH, Lin RD, Hsu FL, Huang YH, Chang HC, Huang CY, Lee MH. J Ethnopharmacol 2006; 106: 353

3. Garcia A, Fulton J.E. J Dermatol. Surg 1996; 22: 443

4. Virador V.M, Kobayashi N, Matsunaga J, Hearing V.J. Anal. Biochem 1999; 270: 207

5. Roosita K, Kusharto CM, Sekiyama M, Fachrurozi Y, Ohtsuka R. J Ethnopharmacol 2008; $115: 72$

6. Soedarsono RS, Harini SR. South Pacific Study 2002; 23: 1

7. Verheij EWM, Snijders CHA. Syzygium aromaticum (L.) Merrill \& PerryIn in Plant Resources of South-East Asia No. 13: Spices, (Eds : C.C. de Guzman, J.S. Siemonsma,). Backhuys Publisher, Leiden, The Netherlands, 1999; 211-218 
8. Srivastava AK, Srivastava SK, Syamsundar KV. Flavour Fragr J 2005; 20: 51

225

9. Arung ET, Shimizu K, Kondo R. Chem Biodiver 2007; 4: 2166

226

10. Park MJ, Gwak KS, Yang I, Choi WS, Jo HJ, Chang JW, Jeung EB, Choi IG. J

227 Microbiol 2007; 45: 460

228

11. Prashar A, Locke IC, Evans CS. Cell Prolif 2006; 39: 241

229

230

12. Viuda-Martos M, Navajas YR, Zapata ES, Fernandez-Lopez J, Perez-Alvarez JA, Flavour Fragr J 2010; 25: 13

231

13. Chaieb K, Hajlaoui H, Zmantar T, Kahla-Nakbi AB, Rouabhia M, Mahdouani K, Bakhrouf A. Phytother Res 2007; 21: 501

234

235

236

237

238

239

240

241

242

243

244

245

246

247 
249 Figure 1. Effect of methanol extracts of the buds of clove (S. aromaticum) on melanin

Figure 8. GC-MC analysis of essential oil of clove (S. aromaticum). 
Figure 1.

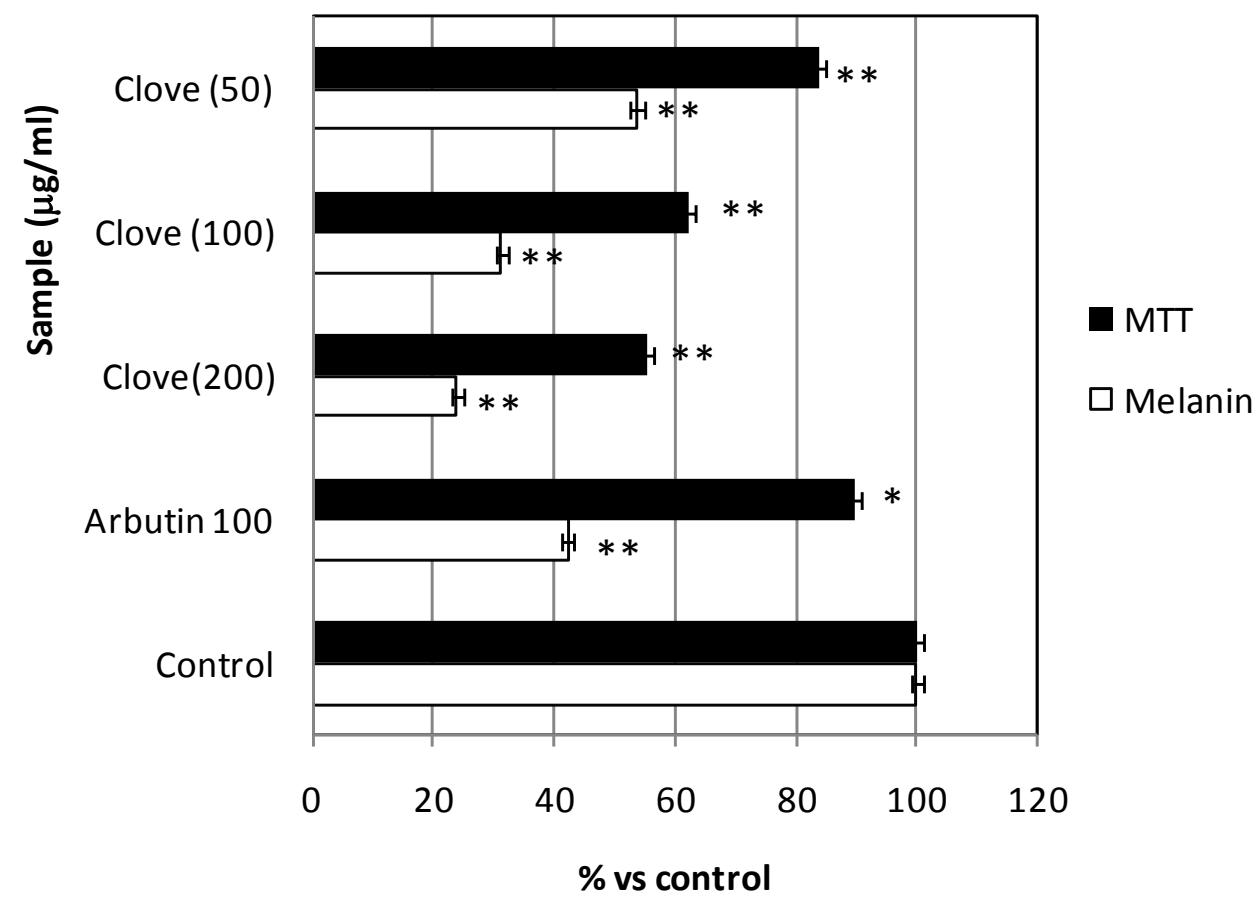

273

274

275 
276 Figure 2.

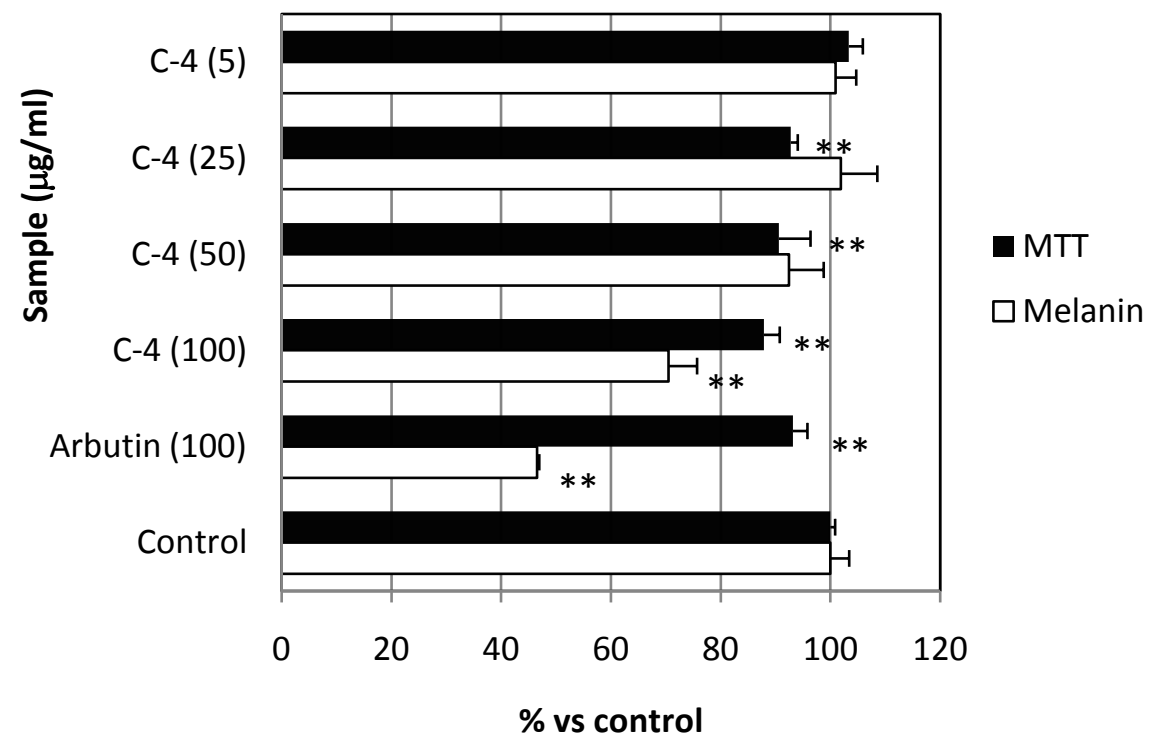

277

278

279 
Figure 3.

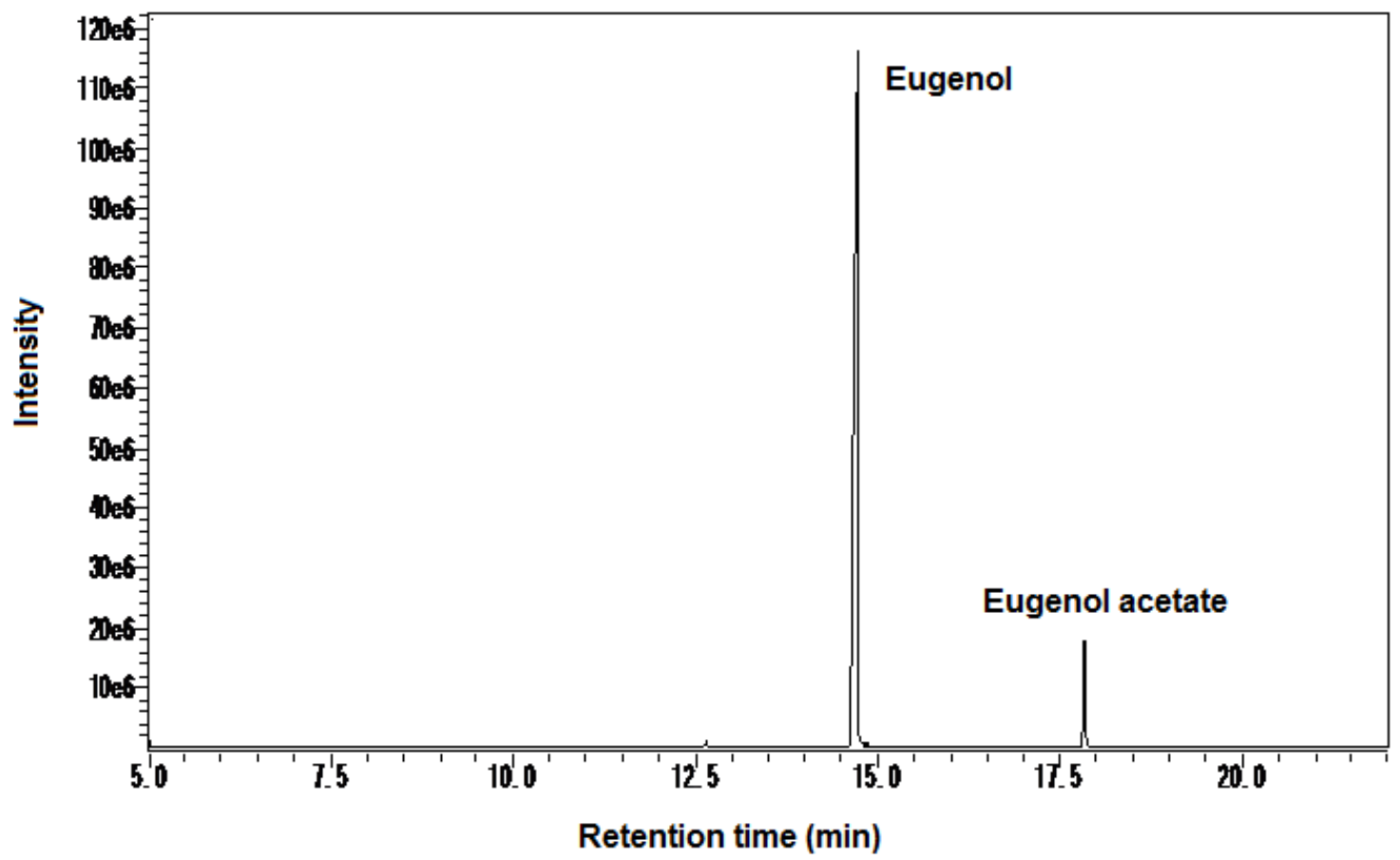

281

282

283

284

285

286

287

288

289

290

291

292

293

294

295

296

297

298

299

300

301 
$302 \quad$ Figure 4.<smiles>C=CCc1ccc(O)c(OC)c1</smiles><smiles>C=CCc1ccc(OC(C)=O)c(OC)c1</smiles>

303

Eugenol Eugenol acetate

304

305

306

307

308

309

310

311

312

313 
$314 \quad$ Figure 5.

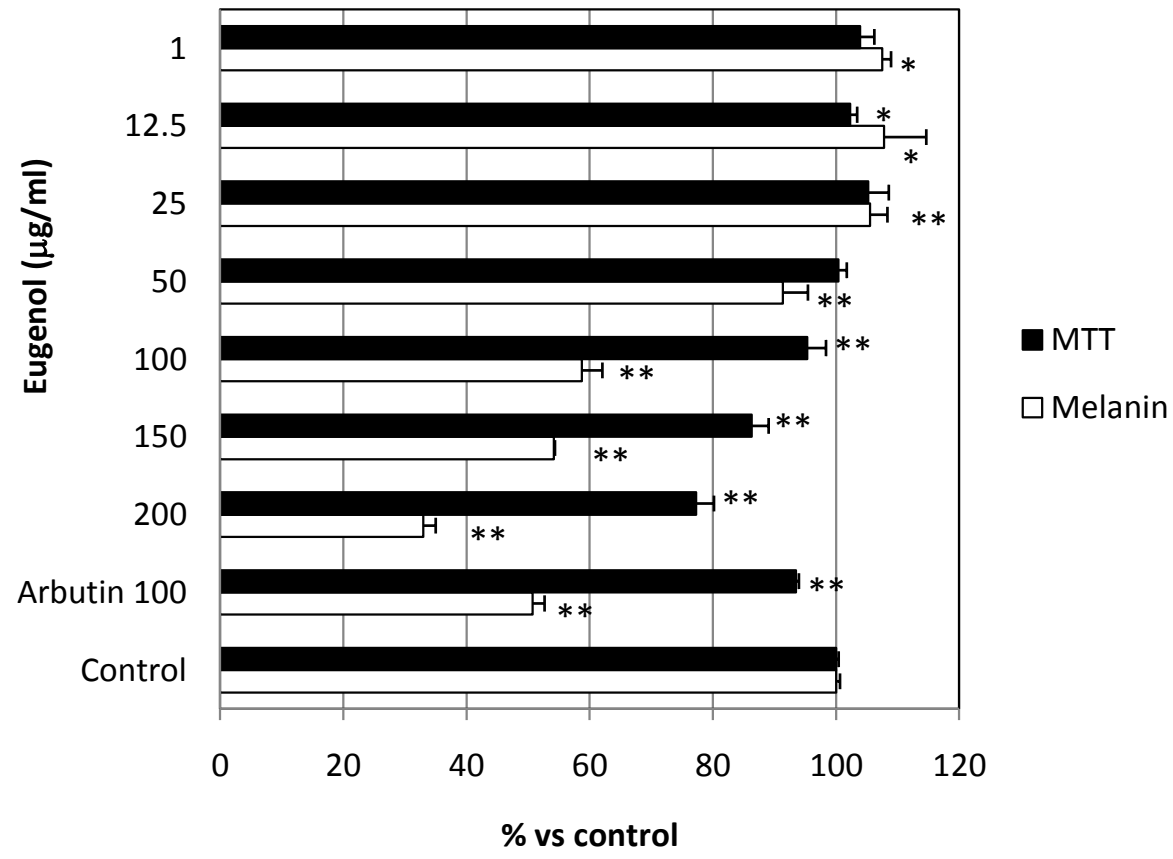

315

316

317 
319

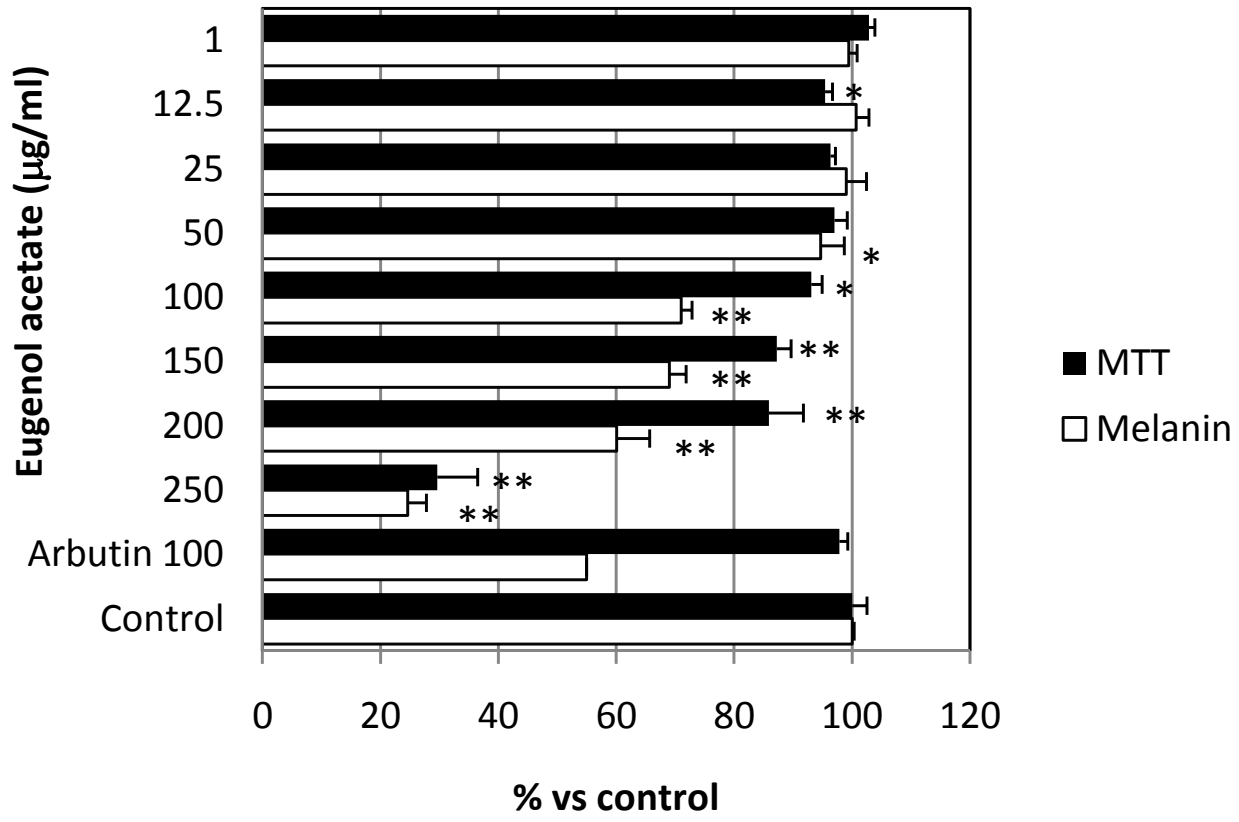

320

321 
Figure 7.

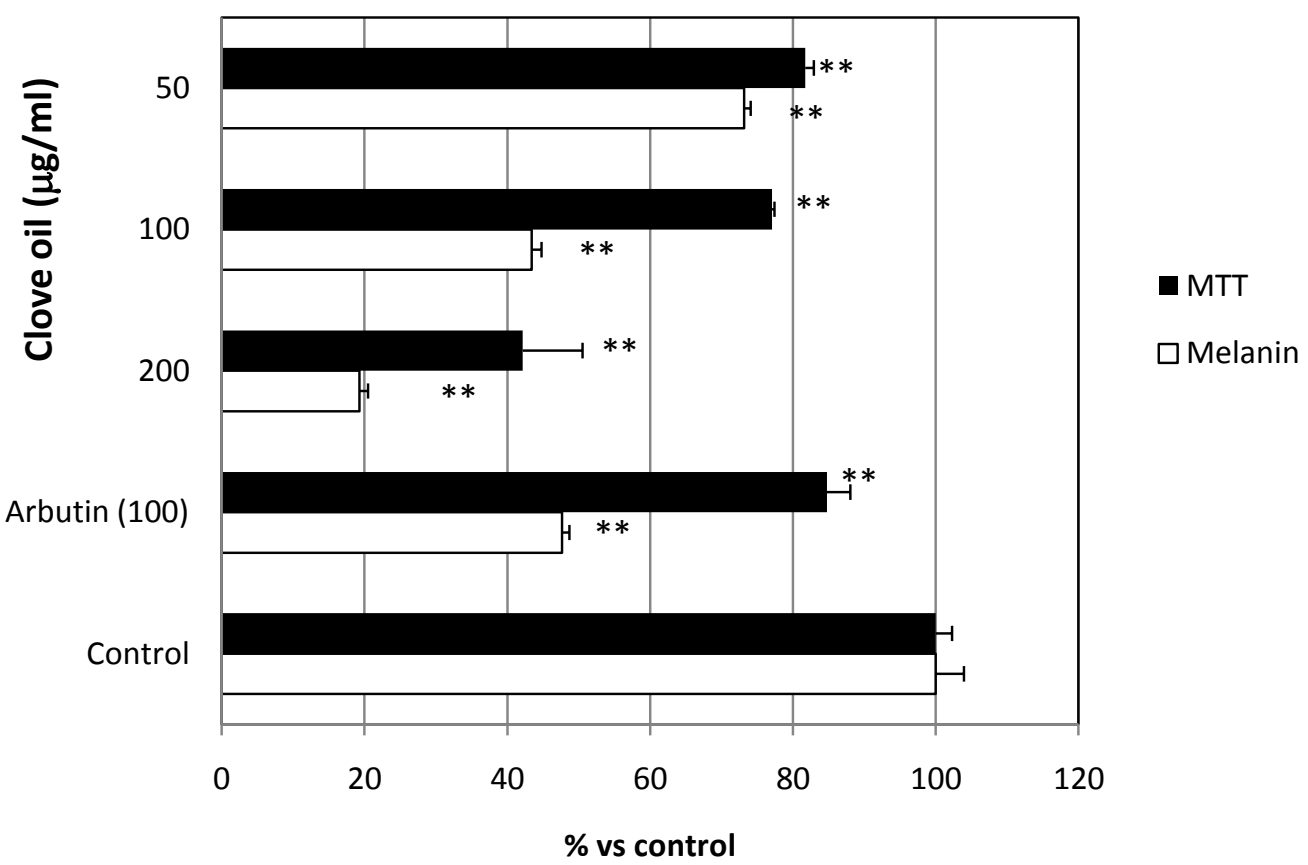

323

324

325 
$326 \quad$ Figure 8.

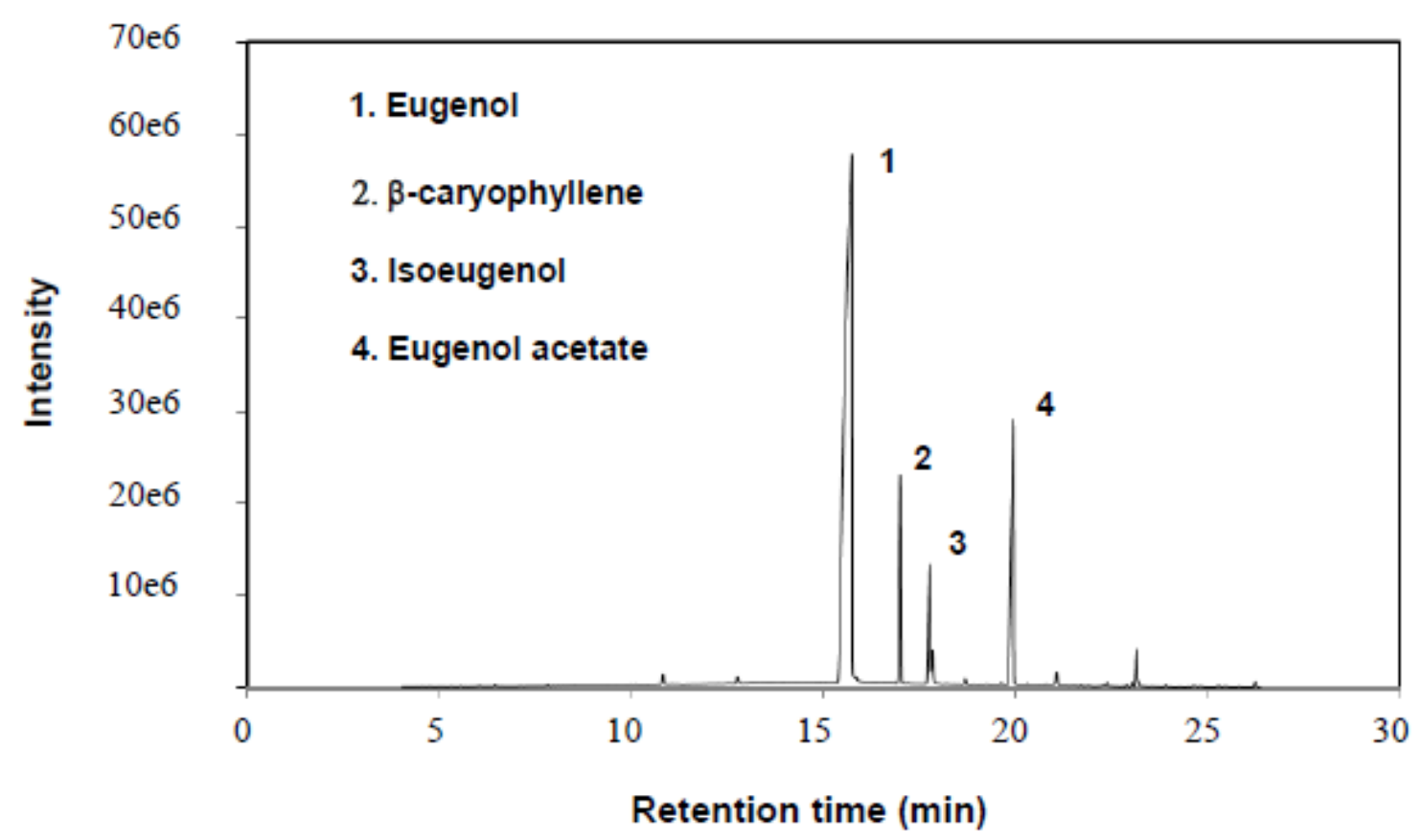

327

328 